\title{
PENGARUH DUKUNGAN SOSIAL, BASIS PENGETAHUAN DAN ORIENTASI PRIBADI TERHADAP KEBERHASILAN WANITA WIRAUSAHA
}

\author{
Oktavia Nabillah Budiman dan Nur Hidayah \\ Program Studi Manajemen Fakultas Ekonomi, Universitas Tarumanagara Jakarta \\ Email:oktavianabillah@gmail.com
}

\begin{abstract}
The purpose of this study is to find out 1) whether there is an influence of social support on the entrepreneurs women in West Jakarta 2) whether there is an influence of the knowledge base on the success of entrepreneurs women in West Jakarta 3) whether there is an influence of personal orientation on the success of entrepreneurs women in West Jakarta. The population in this study were entrepreneurs women in West Jakarta. The sample used in this study is 80 entrepreneur female respondents in West Jakarta. The sampling technique used was nonprobability sample with judgment sampling method.Overall the results of this study are 1) Social support has a positive effect on the success of entrepreneurs women in West Jakarta 2) Knowledge base has a positive effect on the success of entrepreneurs women in West Jakarta 3) Personal orientation has a positive effect on the success of entrepreneurs women in West Jakarta.
\end{abstract}

Keywords: Social Support, Knowledge Base, Personal Orientation, Entrepreneurial Success.

Abstrak: Tujuan penelitian ini adalah untuk mengetahui 1) apakah terdapat pengaruh dukungan sosial terhadap keberhasilan wanita wirausaha di Jakarta Barat 2) apakah terdapat pengaruh basis pengetahuan terhadap keberhasilan wanita wirausaha di Jakarta Barat 3) apakah terdapat pengaruh orientasi pribadi terhadap keberhasilan wanita wirausaha di Jakarta Barat. Populasi dalam penelitian ini adalah wanita wirausaha di Jakarta Barat. Sampel yang digunakan pada penelitian ini yaitu 80 responden wanita wirausaha di Jakarta Barat . Teknik pengambilan sampel yang digunakan yaitu nonprobability sample dengan metode pengambilan sampel judment sampling. Secara keseluruhan hasil dari penelitian ini yaitu 1) Dukungan sosial berpengaruh positif terhadap keberhasilan wanita wirausaha di Jakarta Barat 2) Basis pengetahuan berpengaruh positif terhadap keberhasilan wanita wirausaha di Jakarta Barat 3) Orientasi pribadi berpengaruh positif terhadap keberhasilan wanita wirausaha di Jakarta Barat.

Kata kunci: Dukungan Sosial, Basis Pengetahuan, Orientasi Pribadi, Keberhasilan Wirausaha.

\section{LATAR BELAKANG}

Usaha Mikro, Kecil, dan Menengah (UMKM) di Indonesia memiliki peranan penting dalam perekonomian nasional, terutama dalam kontribusinya terhadap Produk Domestik Bruto (PDB). Usaha Mikro, Kecil, dan Menengah (UMKM) mempunyai peranan yang strategis dalam pembangunan ekonomi nasional. Peran UMKM dalam perekonomian lndonesia dapat dilihat dari kedudukannya sebagai pemain utama dalam kegiatan ekonomi di berbagai sektor, penyedia lapangan kerja yang terbesar, pemain penting dalam pengembangan kegiatan 
ekonomi lokal dan pemberdayaan masyarakat, penciptaan pasar baru dan sumber inovasi, serta sumbangannya dalam menjaga neraca pembayaran melalui kegiatan ekspor

Pengembangan UMKM diharapkan akan meningkatkan stabilitas ekonomi karena menggunakan bahan baku lokal dan memiliki potensi ekspor, sehingga akan membantu menstabilkan kurs rupiah dan tingkat inflasi. Pembangunan UMKM akan menggerakkan sektor riil karena UMKM umumnya memiliki keterkaitan industri yang cukup tinggi. Pengembangan UMKM juga akan meningkatkan pencapaian sasaran kesejahteraan masyarakat lndonesia dimana UMKM menempati posisi strategis untuk mempercepat perubahan structural dalam rangka meningkatkan taraf intermediasi sebagai penyedia jasa pengembangan hidup rakyat dan merupakan wadah kegiatan usaha, teknologi, pemasaran dan informasi usaha bersama bagi produsen maupun konsumen serta mampu berperan dalam memperluas penyediaan lapangan kerja, memberikan kontribusi yang signifikan terhadap pertumbuhan ekonomi, dan memeratakan peningkatan pendapatan serta meningkatnya daya saing dan daya tahan ekonomi nasional.

Berdasarkan pada data partisipasi perempuan terhadap Usaha Mikro Kecil Menengah (UMKM) tahun 2017 jumlah perempuan wirausaha sebesar 12,7 juta orang dan tahun 2018 mengalami peningkatan sebesar 14,3 juta orang, dimana partisipasi wirausaha wanita mencapai lebih $60 \%$ dari 57,83 juta UMKM di Indonesia. Namun faktanya berkembangnya peningkatan jumlah wirausaha perempuan tersebut tidak sebanding dengan kontribusi yang diberikan wirausaha wanita .Sumbangan UMKM perempuan terhadap Produk Dometik Bruto (PDB) baru mecapai 9,1\%. Perlu peningkatan pemberdayaan perempuan agar lebih berkualitas dalam berusaha.

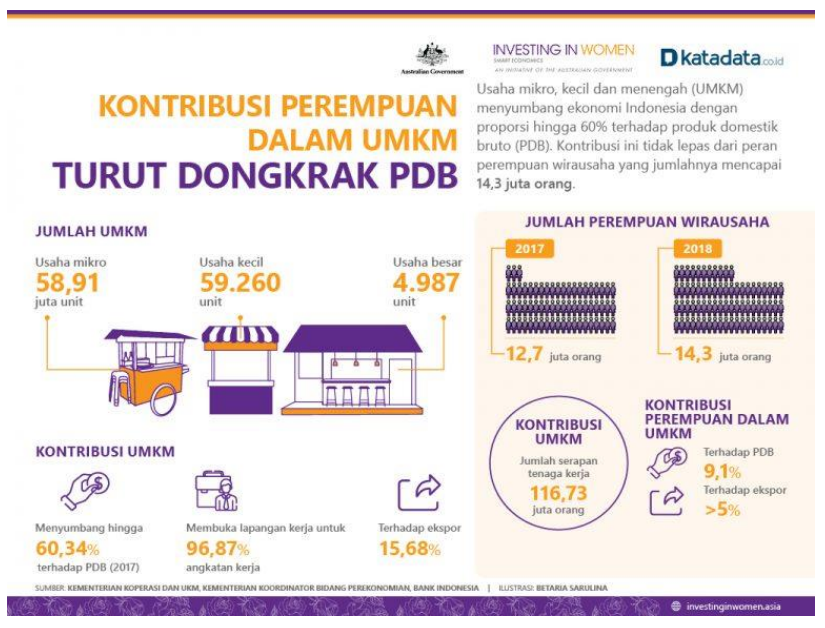

Ketidakberhasilan tersebut akan mempengaruhi ekonomi yang semakin buruk. Indeksi penyebab yang akan terjadi bila terus menerus terjadi tingkat keberhasilan menurun salah satunya yaitu kurangnya pendapatan keluarga. Ketidakberhasilan ini dinyatakan bahwa ternyata Laukhuf \& Malone (2015) menyatakan dukungan keluarga, teman, dan dukungan lingkungan sekitar akan mempermudah individu sekaligus menjadi sumber kekuatan ketika menghadapi permasalahan . Dukungan dari lingkungan terdekat akan membuat individu mampu bertahan menghadapi permasalahan yang terjadi.

Njoki ( 2016 ) menyatakan bahwa pengetahuan kemampuan untuk menciptakan sesuatu yang baru dan berbeda melalui pemikiran kreatif dan tindakan inovatif dapat membantu para wanita pengusaha tersebut untuk memulai dan mengelola usahanya semaksimal mungkin serta mampu mengubah suatu resiko menjadi suatu peluang bagi usahanya dan pengetahuan tentang startegi - strategi pemasaran yang tepat dapat berdampak langsung terhadap keberhasilan usaha bisnis dan pengetahuan tentang teknologi dan media sosial sebagai startegi pemasaran untuk mendorong keberhasilan usaha. 
Itani (2011) menyatakan orientasi pribadi manusia itu sendiri dimana tingginya tingkat kebutuhan keluarga dapat memotivasi pengusaha perempuan untuk mencapai keberhasilan serta kemampuan yang dimiliki perempuan dalam menyeimbangkan kegiatan usaha dengan kehidupan pribadi dapat berkontribusi terhadap keberhasilan pengusaha perempuan dan juga kemampuan serta ketrampilan yang dimilki perempuan dalam memanfaatkan peluang yang ada sehingga dapat mendorong keberhasilan usahanya. Kepercayaan diri yang dimiliki perempuan dalam memutuskan pengambilan resiko serta menyukai adanya tantang dalam berusaha untuk dapat menjadi pendorong keberhasilan usaha.

\section{KAJIAN TEORI}

Cooper and Schindler (2003) dalam Sugiyono (2009:43), mengemukakan bahwa, " $A$ theory is a set of systematically interrelelated concepts, definition, and proposition that are advanced to explain and predict phenomena (fact)." Teori adalah seperangkat konsep, definisi dan proposisi yang tersusun secara sistematis sehingga dapat digunakan untuk menjelaskan dan meramalkan fenomena.

Cooper and Schindler (2003) dalam Sugiyono (2009:44), menyatakan bahwa kegunaan teori dalam penelitian adalah:

1. "Theory narrows the range of fact we need to study"

2. "Theory suggest which research approaches are likely to yield the greatest meaning"

3. "Theory suggest a system for research to impose on data in order to classyfy them in the most meaningful way"

4. "Theory summarizes what is known about object of study and stastes the uniformities that lie beyond immediate observation"

\section{5. "Theory can be used to predict further fact that should be found."}

Teori dan konsep diperlukan sebagai landasan dalam penelitian, dengan kata lain teori dan konsep merupakan pola atau konsep kerangka dasar yang dapat mengarah bagi tercapainya tujuan penelitian.

Dasar teori untuk memahami hubungan dukungan sosial, basis pengetahuan dan orientasi pribadi didasarkan pada Changanti \& Parasuraman,1997;Praag,2003;Davidsson,2006 menunjukan keberhasilan wirausaha sebagai suatu kesuksesan dalam pencapaian tujuan . Tujuan untuk mendapatkan kekayaan, ketenaran atau status sosial . (Brush,2008 \& Cliff,1998) kesuksesan wirausaha diukur melalui pencapaian tujuan, kesuksesan ekonomi dan kesuksesan gaya hidup. Indikator bisnis dan non-bisnis (menghadapi tantangan atau mengatasi hambatan) digunakan untuk mengukur sebuah kesuksesan wanita .

Lener (1997 ) menemukan bahwa seorang wanita mendifinisikan diri mereka sukses karena meraka mampu memenuhi tujuan yang mereka mulai untuk mendirikan usaha mereka sendiri dengan tujuan untuk kemerdekaan pribadi, kebutuhan untuk berprestasi , keseimbangan kebutuhan lebih baik, dan pemenuhan diri. Rani \& hashim (2017) menyatakan sukses diantara perempuan pengusaha dirasakan ketika keseimbangan antara kehidupan dan pekerjaan tercapai. Laily \& Wahyuni (2018) sukses hanyalah kemampuan menjalankan bisnis tanpa ada hambatan. 
Edelman et al (2016) faktor yang mempengaruhi keberhasilan wanita wirausaha yatitu dukungan sosial, basis pengetahuan dan orientasi pribadi. Perempuan pengusaha dapat mengandalkan dukungan moral keluarga sebenarnya dapat berdampak positif pada keberhasilan wirausaha. Wanita yang merasa mendapat dukungan dari keluarganya dalam bentuk kekompakan ,mungkin memiliki lebih banyak kekuatan untuk menangani masalah lain dalam lingkungan bisnis .

Hisrich dan Peters (2000) dukungan keluarga dan teman, dukungan dari orang dekat akan mempermudah individu sekaligus menjadi sumber kekuatan ketika menghadapi permasalahan. Dukungan dari lingkungan terdekat akan membuat individu mampu bertahan menghadapi permasalahan yang terjadi. Sehingga perempuan lebih mampu merespon secara positif tantangan dan kendala yang mempengaruhi kinerja bisnis secara keseluruhan oleh sebab itu butuhkan dukungan untuk menjadi sumber kekutaan.

Gomez \& De Silva (2018) pengetahuan tentang kreatif dan inovasi penting dan berkontribusi terhadap keberhasilan .Hal ini dapat dikaitkan dengan pencapaian pengusaha perempuan yang lebih tinggi yang telah menunjukkan minat inovasi secara signifikan. Pengetahuan IT terbaru adalah penting untuk pengusaha perempuan. Memiliki strategi pemasaran yang tepat dapat membuat atau menghancurkan bisnis. Hal ini dapat berdampak langsung terhadap keberhasilan usaha bisnis. Dimana pengusaha perempuan tidak hanya teknologi terbaru tetapi juga pemanfaatannya terutama dari perspektif pemasaran. Memiliki kebijakan pemasaran suara dapat menyebabkan usaha berpotensi sukses .Eniola dan Dada (2018) bahwa dengan meningkatkan pengetahuan, keterampilan dan pengalaman seorang wirausahawan, secara positif dapat mengubah sumber daya menjadi kekuatan internal perusahaan dan pada akhirnya mencapai kesuksesan.

Njoki ( 2016 ) tingginya kebutuhan untuk control dan kebutuhan untuk keseimbangan kehidupan kerja yang lebih tinggi akan menjadi sukses ,akan mendorong semangat mereka untuk mengejar tujuan mereka dengan penuh semangat, sehingga dampak keberhasilan. Dengan demikian, faktor-faktor seperti ambisi sendiri untuk kontrol dan prestasi dan kemandirian untuk menyeimbangkan kehidupan.

Agarwal \& Lenka (2015) Work-life balance sangat penting dan berkontribusi pada kesuksesan yang sejalan .Para wanita tidak mampu atau tidak mampu mengatasi keseimbangan pekerjaan-kehidupan. Oleh karena itu, pengusaha perempuan harus mengatur waktu mereka dan berbagi peran untuk mengatasi ketegangan. Greenhaus \& Beutell (1985) dapat disimpulkan bahwa seseorang harus puas dengan pekerjaannya dan merasa berkembang baik secara internal maupun eksternal terhadap pekerjaannya agar dapat menyelaraskan pekerjaan dan kehidupannya agar berhasil.

Smith dan Perks ( 2006 ) Orientasi pribadi dengan keterampilan wirausahawan juga perlu melakukan peran fungsional tertentu. Tidak mengherankan Self-confident perempuan, yang percaya bahwa mereka memiliki kuasa atas peristiwa dalam hidup mereka, telah lama menjadi pendukung usaha dan kesuksesan kewirausahaan secara positif dan signifikan terkait erat dengan kinerja.

Model penelitian dalam penelitian ini seperti gambar dibawah ini : 


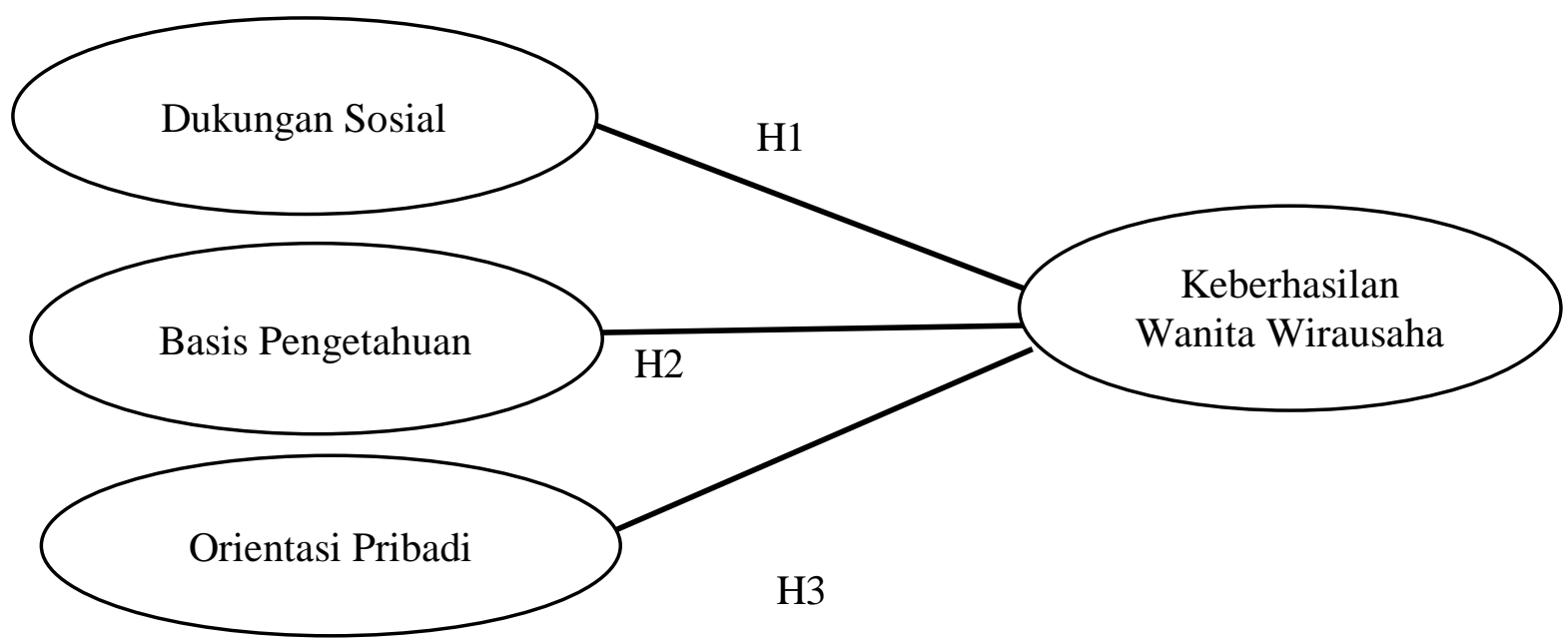

Gambar 2.1 Model peneilitian

Berdasarkan perumusan masalah dan kerangka pemikiran yang ada, dengan tujuan untuk melihat adanya pengaruh antar variabel dukungan social, basis pengetahuan, dan orientasi pribadi terhadap keberhasilan wanita wirausaha maka dapat disusun sebagai berikut :

H1 : Terdapat pengaruh positif dukungan sosial terhadap keberhasilan wanita wirausaha di Jakarta Barat

H2 : Terdapat pengaruh positif basis pengetahuan terhadap keberhasilan wanita wirausaha di Jakarta Barat

H3 : Terdapat pengaruh positif orientasi pribadi terhadap keberhasilan wanita wirausaha di Jakarta Barat

\section{METODOLOGI}

Dalam penelitian ini, peneliti menggunakan metode deskriptif yang bertujuan membuat deskriptif secara sistematis, faktual, dan akurat mengenai fakta-fakta dan sifat-sifat dari populasi. Melalui penerapan metode deskriptif diharapkan peneliti mendapatkan informasi yang tepat dan akurat serta gambaran korelasi dari pengaruh dukungan sosial $\left(\mathrm{X}_{1}\right)$, basis pengetahuan $\left(\mathrm{X}_{2}\right)$ dan orientasi pribadi $\left(\mathrm{X}_{3}\right)$ terhadap keberhasilan wanita wirausaha $(\mathrm{Y})$..

Pada penelitian ini, populasi yang diambil adalah wanita wirausaha di Jakarta Barat, dengan sampel yaitu pengusaha wanita di Jakarta Barat sebanyak 80 responden ,maka itu kuesioner diberi judul: "Pengaruh Dukungan Sosial, Basis pengetahuan dan Orientasi Pribadi terhadap Keberhasilan Wanita Wirausaha di Jakarta Barat".

Teknik pemilihan sampel yang digunakan dalam penelitian ini adalah teknik tak acak purposive. Teknik ini digunakan atas dasar kemudahan unsur populasi untuk dijangkau. Untuk itu, unsur populasi yang lebih mudah dapat diperoleh datanya untuk itu unsur itulah yang dapat dijadikan sampel.

Jenis data yang dapat digunakan dalam penelitian ini adalah data primer. Data primer adalah seluruh data yang telah dikumpulkan sendiri oleh peneliti agar dapat menjawab suatu permasalahan penelitiannya.

Skala yang dipakai adalah interval dengan teknik skala Likert yang dinyatakan dalam lima kategori, yaitu(1) sangat tidak setuju, (2) tidak setuju, (3) ragu-ragu, (4) setuju dan (5) sangat setuju. 


\section{HASIL UJI STATISTIK}

Pengujian validitas data dalam penelitian ini diukur dengan menggunakan nilai loading factor, convergent validity, dan discriminant validity. Nilai loading factor harus dapat lebih besar dari 0,6 dan jika nilai loading faktor dibawah dari 0,4 maka indikator tersebut dapat dihapuskan. Untuk mengukur nilai convergent validity dapat diukur melalui nilai Average Variance Extracted (AVE) yaitu harus dapat lebih besar dari 0,5 dan nilai loading faktor diatas 0,6 . nilai loading factors dalam penelitian ini mempunyai nilai diatas 0,6. Dengan nilai tertinggi yaitu keberhasialan wanita wirausaha 0,950 dan nilai terendah yaitu orientasi pribadi 0,869. Sehingga dapat disimpulkan bahwa semua indikator yang digunakan dalam penelitian ini telah memenuhi syarat.

Pengujian reliabilitas data dalam penelitian ini menggunakan Cronbach's alpha dan composite reliability untuk dapat menguji reliabilitas. Suatu data dapat dinyatakan reliabel jika hasil dari nilai Cronbach's alpha > 0,6 dan juga mempunyai nilai composite reliability (CR) lebih besar atau sama dengan 0,7. Berikut ini merupakan hasil dari nilai cronbach's alpha dan composite reliability. Cronbach's alpha dukungan sosial mempunyai nilai 0,873 , basis pengetahuan mempunyai nilai 0,859 , orientasi pribadi mempunyai nilai 0,935 , dan selanjutnya keberhasilan wanita wirausaha mempunyai nilai 0,953 dan composite reliability dukungan sosial mempunyai nilai 0,922 , basis pengetahuan sebesar 0,914 , orientasi pribadi 0,954 dan selanjutnya keberhasilan wanita wirausaha sebesar 0,966 .

$\mathrm{R}^{2}$ digunakan untuk menilai variasi pengaruh antara variabel independen terhadap variabel dependen (Ghozali, 2014). Apabila nilai R-square diatas 0,75 maka mempunyai pengaruh yang kuat, sedangkan 0,5- 0,74 mempunyai pengaruh yang sedang dan 0,25-0,49 memiliki pengaruh yang lemah. Besarnya koefisien determinan $\left(\mathrm{R}^{2)}\right)$ pada penelitian ini adalah sebesar 0,703 yaitu berarti sebesar 70,3\% dari variabel dependen keberhasilan wanita wirausaha dapat dijelaskan oleh variabel-variabel independen yang diteliti dalam penelitian ini yaitu dukungan sosial, basis pengetahuan, dan orientasi pribadi. Sedangkan sisanya yaitu sebesar 29,7\% dapat dijelaskan oleh variabel-variabel independen lain yang tidak dimasukkan dalam penelitian ini

Pengujian path coefficients memiliki nilai variabel dukungan sosial terhadap keberhasilan wanita wirausaha yaitu sebesar 0,263. Variabel basis pengetahuan terhadap keberhasilan wanita wirausaha yaitu sebesar 0,228 . Variabel orientasi pribadi terhadap keberhasilan wanita wirausaha yaitu sebesar 0,432

Pengujian Goodness of Fit (GoF)Untuk dapat melakukan pengujian kecocokan model dalam penelitian ini, nilai GoF (Goodness of Fit) dapat dihitung dengan cara manual dengan memasukan nilai AVE dan nilai koefisien determinasi. Berikut ini merupakan perhitungan nilai Goodness of Fit (GoF):

$$
\begin{aligned}
\text { AVE } & =(0,798+0,780+0,838+0,875): 4 \\
& =0,823 \\
\mathrm{R}^{2} & =0,703 \\
\text { Maka, } & \\
\text { GoF } & =\sqrt{\text { AVE x R }} \\
& =\sqrt{0,823 \times 0,703} \\
& =0,761
\end{aligned}
$$


Dari hasil perhitungan diatas, maka dapat disimpulkan bahwa nilai 0,761 memiliki Goodness of Fit (GoF) yang tinggi itu dikarenakan hasil tersebut lebih besar dari batas minimum yang ada pada ketentuan dalam GoF Large $=0,36$, yang artinya model tersebut mempunyai kemampuan yang tinggi dalam menjelaskan data empiris sehingga, dapat dikatakan bahwa model tersebut valid.

Pengujian Hipotesis yang telah dilakukan dalam penelitian ini untuk dapat menentukan apakah hipotesis-hipotesis yang telah dibuat dalam penelitian ini mempunyai pengaruh yang siginifikan. Pengujian hipotesis penelitian ini dilihat dari nilai t-statistik atau p-values.

$\mathrm{H}_{1}$ : Dukungan sosial berpengaruh positif terhadap keberhasilan wanita wirausaha di Jakarta Barat

Nilai path coefficient dukungan sosial terhadap keberhasilan wanita wirausaha menunjukan nilai yang positif sebesar 0,263 . Nilai P-value yang didapatkan dari hasil pengujian sebesar 0,013 yang berarti hasil tersebut signifikan karena nilai tersebut berada dibawah batas minimalnya yaitu 0,05 . Kemudian, T-statistics dukungan sosial terhadap keberhasilan wanita wirausaha sebesar 2,500 dimana hasil tersebut memiliki nilai yang lebih tinggi dari batas nilai t-tabel yaitu 1,96. Jadi dari penjabaran di atas maka, variabel dukungan sosial berpengaruh positif dan signifikan terhadap keberhasilan wanita wirausaha di Jakarta Barat.

$\mathrm{H}_{2}$ : Basis pengetahuan berpengaruh positif terhadap keberhasilan wanita wirausaha di Jakarta Barat

Nilai path coefficient basis pengetahuan terhadap keberhasilan wanita wirausaha menunjukan nilai yang positif sebesar 0,228 . Nilai P-value yang didapatkan dari hasil pengujian sebesar 0,024 yang berarti hasil tersebut signifikan karena nilai tersebut berada dibawah batas minimalnya yaitu 0,05 . Kemudian, $\mathrm{T}$-statistics basis pengetahuan terhadap keberhasilan wanita wirausaha sebesar 2,261 dimana hasil tersebut memiliki nilai yang lebih tinggi dari batas nilai t-tabel yaitu 1,96. Jadi dari penjabaran di atas maka, variabel basis pengetahuan berpengaruh positif dan signifikan terhadap keberhasilan wanita wirausaha di Jakarta Barat

$\mathrm{H}_{3}$ : Orientasi pribadi berpengaruh positif terhadap keberhasilan wanita wirausaha di Jakarta Barat

Nilai path coefficient orientasi pribadi terhadap keberhasilan wanita wirausaha menunjukan nilai yang positif sebesar 0,432 . Nilai P-value yang didapatkan dari hasil pengujian sebesar 0,000 yang berarti hasil tersebut signifikan karena nilai tersebut berada dibawah batas minimalnya yaitu 0,05 . Kemudian, T-statistics orientasi pribadi terhadap keberhasilan wanita wirausaha sebesar 4,332 dimana hasil tersebut memiliki nilai yang lebih tinggi dari batas nilai t-tabel yaitu 1,96. Jadi dari penjabaran di atas maka, variabel orientasi pribadi berpengaruh positif dan signifikan terhadap keberhasilan wanita wirausaha di Jakarta Barat

Penjelasan uji hipotesis di atas, maka dapat dikatakan bahwa variabel dukungan sosial, basis pengetahuan dan orientasi pribadi memiliki pengaruh yang signifikan terhadap keberhasilan wanita wirausaha di Jakarta Barat .

\section{DISKUSI}

Hipotesis pertama $\left(\mathrm{H}_{1}\right)$ menunjukkan bahwa dukungan sosial merupakan prediktor yang positif dan signifikan terhadap keberhasilan wanita wirausaha di Jakarta Barat Perempuan pengusaha dapat mengandalkan dukungan moral keluarga sebenarnya dapat berdampak positif pada keberhasilan wirausaha. Sesuai dengan pernyataan Hisrich dan Peters (2000), dukungan keluarga dan teman, dukungan dari orang dekat akan mempermudah individu sekaligus menjadi sumber kekuatan ketika menghadapi 
permasalahan. Dukungan dari lingkungan terdekat akan membuat individu mampu bertahan menghadapi permasalahan yang terjadi. Hasilnya Baron (2008), perempuan lebih mampu merespon secara positif tantangan yang mempengaruhi kinerja bisnis secara keseluruhan. Pengusaha wanita di Jakarta Barat menyatakan bahwa dengan banyaknya dukungan ,dorongan dari teman, keluarga yang diterimanya akan sangat membantu wanita wirausaha dalam mempengaruhi keberhasilan usaha.

Hipotesis kedua $\left(\mathrm{H}_{2}\right)$ menunjukkan bahwa basis pengetahuan merupakan prediktor yang positif dan signifikan terhadap keberhasilan wanita wirausaha di Jakarta Barat. Gomez et al (2017) menyatakan bahwa pengetahuan tentang kreatif dan inovasi penting dan berkontribusi terhadap keberhasilan. Pencapaian pengusaha perempuan yang lebih tinggi telah menunjukkan minat inovasi secara signifikan.Eniola dan Dada (2018) bahwa dengan meningkatkan pengetahuan, keterampilan dan pengalaman seorang wirausahawan, secara positif dapat mengubah sumber daya menjadi kekuatan internal perusahaan dan pada akhirnya mencapai kesuksesan. Pada pengusaha wanita di Jakarta Barat menyatakan adanya kemampuan dan keterampilan yang dimilikinya seperti : melihat peluang-peluang bisnis dan menetukan startegi-strategi yang tepat akan mendukung dan mempengaruhi keberhasilan usaha.

Hipotesis ketiga $\left(\mathrm{H}_{3}\right)$ menunjukkan bahwa orientasi pribadi merupakan variabel yang berpengaruh positif dan signifikan terhadap keberhasilan wanita wirausaha. Njoki (2016) menyatakan tingginya kebutuhan untuk kontrol dan kebutuhan untuk menyeimbangan kehidupan dan kerja akan mendorong semangat untuk mengejar tujuan mereka dengan penuh semangat, sehingga berdampak pada keberhasilan. Faktor-faktor seperti ambisi sendiri untuk kontrol, prestasi dan kemandirian untuk menyeimbangkan kehidupan. Smith dan Perks (2006) menyatakan dengan keterampilan wirausahawan juga perlu melakukan peran fungsional . Self-confident perempuan, yang percaya bahwa mereka memiliki kuasa atas peristiwa dalam hidup mereka, telah lama menjadi pendukung usaha dan kesuksesan kewirausahaan secara positif dan signifikan terkait erat dengan kinerja. Pada pengusaha wanita di Jakarta Barat menyatakan bahwa semakin mudah untuk menyeimbangkan antara kehidupan dan pekerjaan akan mempengaruhi terhadap keberhasilan usaha.

\section{KESIMPULAN}

Berikut adalah hasil penelitian dan pembahasan, maka dapat diambil beberapa kesimpulan sebagai berikut:

1. Dukungan sosial berpengaruh positif dan signifikan terhadap keberhasilan wanita wirausaha di Jakarta Barat.

2. Basis pengetahuan berpengaruh positif dan signifikan terhadap keberhasilan wanita wirausaha di Jakarta Barat

3. Orientasi pribadi berpengaruh positif dan signifikan terhadap keberhasilan wanita wirausaha di Jakarta Barat

Saran. Dari hasil analisis dan penjabaran keterbatasan dalam penelitian ini maka peneliti akan memberikan saran yang mungkin akan bermanfaat untuk penelitian selanjutnya yang akan melakukan penelitian sejenis sebagai berikut:

a. Penelitian Selanjutnya

1. Pada penelitian selanjutnya disarankan untuk menambahkan variabel-variabel independen lainnya seperti motivasi dan lingkungan. 
2. Pada penelitian selanjutnya dapat memenentukan sampel yang besarnya lebih dari 80 responden sehingga penelitian selanjutnya dapat lebih beragam macam jumlah respondennya. Pada penelitian selanjutnya juga dapat memperluas populasi seperti pengusaha wanita di Jakarta secara keseluruhan.

3. Pada penelitian selanjutnya juga dapat melakukan penyebaran kuesioner dengan dua cara seperti mengorvervasi tempat usaha untuk mencegah pengisian kuesioner tidak tepat dan juga dapat melalui google form dan disebarkan melalui media sosial.

b. Praktis

1. Pada wanita wirausaha diharapkan melalui penelitian ini dapat memberikan masukan positif mengenai hal- hal yang dapat meningkatkan dukungan sosial, basis pengetahuan dan orientasi pribadi terhadap keberhasilan wanita dalam menjalankan usahanya .

2. Hasil penelitian ini diharapkan dapat menjadi dasar dari perbaikan serta mengevaluasi mengenai dukungan sosial, basis pengetahuan dan orientasi pribadi terhadap keberhasilan wanita wirausaha di Jakarta barat.

\section{DAFTAR PUSTAKA}

Chatterjee, N., Das, N., \& Srivastava, N. K. (2019). A structural model assessing key factors affending woman's entrepreneurial success. 11 No. 1, 125 - 136.

Ebrashi, R. E. (2013). Social entrepreneuship theory and sustainable social impact. Social Resposibility Journal, 188-209.

Farrukh, M. d. (2017). Entrepreneurship intention : the role of family factors, personality traits and self-efficacy. world of journal entreprenuership, management and sustainable development, 303-317.

Fokus, A. D. (2019). Factors influencing the success of womaan entrepreneurs in factor driven economies. 60 No. 1, 22- 28.

Ghozali, I., \& Latan , H. (2012). Partial Least Square : Konsep, Teknik dan Aplikasi SmartPLS 2.0 M3 . Semarang : Badan penerbit Universitas Dipenogoro.

Kaciak, E., \& Welsh, D. H. (2019). Woman entrepreneurs and work life interface : The impact of sustainable economic on success. 2-5.

Kanapathillai , K., \& azam , S. F. (2019). woman entrepreneurs path to success : an investigation of the critical success factors in Malaysia. 3, 109 - 111.

le, H., Newman, A., Menzies, J., Zheng, C., \& Fermelis, J. (2020). Work life balance in Asia . 2-9.

Sugiyono. (2011). Metode penelitian kuantitatif, kualitatif dan R\&D. Bandung: Alfabeta.

Suprato. (2008). Statistik Teori dan Aplikasi. Jakarta: Penerbit Erlangga. .

Welsh, D. H., \& Kaciak, E. (2019). Family enrichment and women entrepreneurial success: the effect of family interference. 2-9 .

Yukondi, V., \& Cante, J. M. (2020). The Influence of Family, Human, Social Capital \& Government Support Services on Women Entrepreneurial Start-up Decisions: A Qualitative Study. 9, 308-314. 